\title{
Happiness in early childhood
}

\author{
Rita Eka Irzaty \\ Department of Psychology, Universitas Negeri Yogyakarta, Jl. Colombo No. 1, Depok, Sleman, \\ Yogyakarta 55281, Indonesia \\ rita_ekaizzaty@uny.ac.id
}

\begin{abstract}
This research was conducted based on three considerations. Firstly, childhood is a critical developmental stage that forms the foundation for the psychological well-being and future learning development of children. Secondly, the prevalence of child and adolescent behavioral problems is increasing, assumed to be caused by unhappiness. Thirdly, studies related to happiness in early childhood in Indonesia are still lacking. Therefore, this study aims to explore the meaning, situation, and parties associated with happiness in children. Our study is exploratory using a qualitative approach. The respondents include 51 children aged 4 to 6 years. The research took place in the Special Region of Yogyakarta. We interviewed the respondents and later analyzed the data using content analysis. The latter consist of three coding steps: open coding, axial coding, and selective coding. The results show that, 1) the meaning of happiness refers to positive affects (55\%), activities (28.9\%), getting something (8.89\%), positive physical conditions $(4.44 \%)$, and affiliation $(2.22 \%), 2)$ The situations that make children happy are activities $(36.61 \%)$, learning $(11.61 \%)$, entertainment $(9.82 \%)$, and sports $(2.62 \%), 3)$ The parties who make children happy are families $(77.92 \%)$, extended families (3.90\%), non-family $(19.48 \%)$, God $(1.30 \%)$ and toys $(1.30 \%)$.
\end{abstract}

Keywords: happiness, early childhood

\section{Introduction}

Childhood is a critical stage of development that forms the foundation for psychological well-being and future learning development (UNICEF, 2016). One of the factors that influence a child's development is the psychological well-being, often known as happiness (Husted, 2017; Anand, 2016). Holder (2012) summarized that, based on various research, happiness is proven to affect the creativity, cognitive development, and emotional maturity of children. These factors also influence their ability to adapt to the social environment.

However, not all children would experience happiness throughout their stage of development. Some research shows that psychological ill-being or unhappiness is indicated by the emotional and behavioral problems that occur in childhood which affect the developmental process and daily life (Shoshani \& Sione, 2017). Similarly, Gimpel, Holland, Gelder, Lopez, and Andreasen (in Wiguna, 2010) found that emotional and behavioral problems in children have an impact on cognitive development disorders, learning diffi- culties caused by low concentration, poor memory, and inappropriate behaviour, causing an increase in delinquency and crime in adulthood. Furthermore, various emotional and behavioral problems in children and adolescents are caused by physical illness, inadequate parenting, domestic violence, poor peer relations, and poverty. Multiple types of stressors can precipitate children to perceive the environment and themselves negatively, resulting in various kinds of emotional and behavioral problems (e.g., destructive and impulsive behavior, disruption of friendships).

Researches related to happiness have long been one of the main focuses in psychology research, especially in positive psychology and other social sciences (Martin, Perles, \& Canto, 2010). Happiness is a positive emotional state which is subjectively determined by each person (Snyder \& Lopez, 2007). Modern western psychologists, especially those who are focusing on postmaterialism, view that the meaning of happiness includes prosperity, satisfaction, joy, pleasure or state of delight, and meaningfulness of life, which ultimately plays a role in the psychological wellbeing and social health of the community 
(Demirbatir, 2015; Ghasempour, et. al., 2013; Lyubomirsky, 2005; Diener, et. al. in Snyder \& Lopez, (2007); Seligman, 2002).

Theoretically, psychological well-being itself is a small part of the concept of wellbeing, broadly referred to as the optimal psychological functions and experiences (Ryan \& Deci, 2001). Psychological well-being is seen as a eudaimonic approach (a human development that focuses on the idea of living a good life) or happiness based on the meaning of life goals and actualizing the potentials for prosperity, can be defined as a condition of individual well-being that functions positively. The characteristics of individuals with psychological well-being show self-acceptance, personal growth, purpose in life, environmental mastery, autonomy, and positive relations with others (Rabito-Alcon \& RodriguezMolina, 2016; Ryff, 2014; Snyder \& Lopez, 2007; Ryff \& Singer, 2006; Keyes, Shmotkin, \& Ryff, 2002; Ryan \& Deci, 2001; Ryff \& Keyes, 1995). Related to this definition, humans have two positive functions to improve their psychological well-being. Firstly, individuals can distinguish between positive and negative things and define happiness as a balance between the two; and second, individuals are emphasizing life satisfaction as the primary key to achieving well-being (Ryff \& Keyes, 1995).

Many experts agree that our pleasure, happiness, and life satisfaction reflects our psychological well-being (Rabito-Alcon \& Rodriguez-Molina, 2016; Guney, 2009; Ryan \& Deci, 2001; Ryff \& Keyes, 1995). In other words, the level of psychological well-being and satisfaction towards life will increase as a person becomes happier. Another study also supported the idea that happiness is one of the critical factors that influence one's psychological well-being (Ghasempour et al., 2013). Our study is in line with Seligman (2002) who stated that happiness that comes from our psychological strength helps to ensure a pleasant and meaningful life. Based on that explanation, we can conclude that psychological well-being is an individual condition characterized by the happiness that derives from self-acceptance, personal growth, life goals, environmental mastery, autonomy or independence, and positive relationships with others.

Based on the above explanation, our study aims to explore the meaning of psychological well-being, situations, and parties or conditions involved. The research questions proposed are: (1) What is the meaning of happiness in early childhood?; (2) What situation makes children happy?; and (3) Who makes children the happiest?

\section{Method}

The research used a qualitative approach with the aim of exploring and understanding the meaning of subjective well-being for some individuals. This also includes examining the meaning, situation, and parties that relates to psychological well-being. Fifty one children, aged 4-6 years old, were involved as the research subject. The research was located in the Special Region of Yogyakarta. Written documents in this study were in the form of verbatim transcripts of the interviews.

We used qualitative interviews to obtain knowledge about the subjective meaning that one has about the topic of the study. Data collection was done through in-depth interviews using open questions arranged in an interview guide. Data analysis included the following steps: (1) Reviewing all available data from various existing data sources, namely from interviews and observations; (2) Data from previous studies were reduced or made into abstraction. Abstraction is an attempt to summarize the core, process, and statements needed; (3) The researcher conducted content analysis by compiling the abstraction in units to be categorized. Categorization was conducted using coding. According to Strauss and Corbin (in Putri \& Wicaksono, 2017), there are three steps in the coding process, namely; (a) Open Coding: The process of identifying categories, properties, and dimensions; (b) Axial Coding: The process of organizing data by developing relationships between existing categories; (c) Selective Coding: The process of selecting the most basic categories, then validating relationships between categories that are systematically linked; (4) The final step of this analysis process is checking the validity of the data. 


\section{Findings and Discussion}

Findings

\section{The Meaning of Happiness}

Based on the understanding of children aged 4 to 6 years, the meanings of happiness are positive affection at $55 \% \quad(35.56 \%$ for positive emotions, such as happy, cheerful, delight, joy; expressions such as laughing and smiling at $15.56 \%$, and the absence of negative emotions such (e.g., sad, not crying) at $4.4 \%$ ), activities at $28.9 \%$ (20\% playing, $4.44 \%$ traveling, $2 \%$ each for helping and learning), getting something at $8.89 \%$, positive physical condition (e.g., not feeling tired, healthy) at $4.44 \%$, as well as showing affiliation (based on number of friends owned) of $2.22 \%$.

Data distribution shows that children interpret happiness as engaging in play activities and showing positive emotions. There are 18 children $(20 \%$ of the $28.89 \%$ who responded) chose play activity as a representation of happiness. Meanwhile, as many as 16 children $(17.76 \%)$ remain to believe that positive emotion is the best predictor of happiness. The results regarding the meaning of happiness can be seen in Table 1 .

Table 1. The meaning of happiness

\begin{tabular}{|c|c|c|}
\hline The Meaning of Happiness & Numbers & Percentage \\
\hline Positive affect & 50 & $55.56 \%$ \\
\hline Positive emotions & 32 & $35.56 \%$ \\
\hline Happy & 16 & $17.78 \%$ \\
\hline Cheerful & 6 & $6.67 \%$ \\
\hline Delight & 6 & $6.67 \%$ \\
\hline Joy & 4 & $4.44 \%$ \\
\hline Expressions & 14 & $15.56 \%$ \\
\hline Laughing & 8 & $8.89 \%$ \\
\hline Smiling & 6 & $6.67 \%$ \\
\hline Absence of negative emotions & 4 & $4.44 \%$ \\
\hline Not sad & 2 & $2.22 \%$ \\
\hline Not crying & 2 & $2.22 \%$ \\
\hline Activities & 26 & $28.89 \%$ \\
\hline Activities & 26 & $28.89 \%$ \\
\hline Playing & 18 & $20.00 \%$ \\
\hline Going out & 4 & $4.44 \%$ \\
\hline Helping parents & 2 & $2.22 \%$ \\
\hline Studying & 2 & $2.22 \%$ \\
\hline Getting something & 8 & $8.89 \%$ \\
\hline Being given to & 6 & $6.67 \%$ \\
\hline good & 2 & $2.22 \%$ \\
\hline Positive physical conditions & 4 & $4.44 \%$ \\
\hline Positive physical conditions & 4 & $4.44 \%$ \\
\hline Not feeling tired & 2 & $2.22 \%$ \\
\hline Healthy & 2 & $2.22 \%$ \\
\hline Affiliation & 2 & $2.22 \%$ \\
\hline Having many friends & 2 & $2.22 \%$ \\
\hline Grand Total & 90 & $100.00 \%$ \\
\hline
\end{tabular}


Table 2. The situations that make children happy

\begin{tabular}{|c|c|c|}
\hline Situations that Make Children Happy & Numbers & Percentage \\
\hline Activities & 79 & $70.54 \%$ \\
\hline Activities & 41 & $36.61 \%$ \\
\hline Learning & 13 & $11.61 \%$ \\
\hline Traveling & 11 & $9.82 \%$ \\
\hline Eating & 8 & $7.14 \%$ \\
\hline Reading books & 2 & $1.79 \%$ \\
\hline Helping mother & 1 & $0.89 \%$ \\
\hline Writing stories & 1 & $0.89 \%$ \\
\hline Drawing & 1 & $0.89 \%$ \\
\hline Cleaning & 1 & $0.89 \%$ \\
\hline Watering flowers & 1 & $0.89 \%$ \\
\hline Reflecting on the mirror & 1 & $0.89 \%$ \\
\hline Eating and drinking & 1 & $0.89 \%$ \\
\hline Going out with family & 1 & $0.89 \%$ \\
\hline Going back to hometown & 1 & $0.89 \%$ \\
\hline Playing & 23 & $20.54 \%$ \\
\hline Playing & 23 & $20.54 \%$ \\
\hline Entertainment & 11 & $9.82 \%$ \\
\hline Holiday & 7 & $6.25 \%$ \\
\hline Reading comic books & 3 & $2.68 \%$ \\
\hline Watching TV/movies & 1 & $0.89 \%$ \\
\hline Sports & 3 & $2.68 \%$ \\
\hline Playing soccer & 2 & $1.79 \%$ \\
\hline Playing badminton & 1 & $0.89 \%$ \\
\hline Getting something & 14 & $12.50 \%$ \\
\hline Receiving a gift & 14 & $12.50 \%$ \\
\hline Technology & 9 & $8.04 \%$ \\
\hline Playing gadgets/HP & 9 & $8.04 \%$ \\
\hline Affiliation & 5 & $4.46 \%$ \\
\hline Social Interaction & 5 & $4.46 \%$ \\
\hline Being loved by father & 2 & $1.79 \%$ \\
\hline Family gathering & 1 & $0.89 \%$ \\
\hline Seeing many people smile & 1 & $0.89 \%$ \\
\hline Joking around & 1 & $0.89 \%$ \\
\hline Special day & 3 & $2.68 \%$ \\
\hline Special Day & 3 & $2.68 \%$ \\
\hline Birthday & 3 & $2.68 \%$ \\
\hline Achievement & 2 & $1.79 \%$ \\
\hline Achievement & 2 & $1.79 \%$ \\
\hline Being complimented by teacher & 1 & $0.89 \%$ \\
\hline In heaven & 1 & $0.89 \%$ \\
\hline Grand Total & 112 & $100.00 \%$ \\
\hline
\end{tabular}




\section{The Situations that Make Children Happy}

As seen in Table 2, the situations that cause psychological well-being (happiness) are activities $(36.61 \%)$ such as learning, traveling, eating, reading books, helping mother, writing stories, drawing, cleaning, watering flowers, reflecting on the mirror, eating and drinking; which includes playing (20.54\%), studying in kindergarten (11.61\%), entertainment $(9.82 \%$ : going on vacation, reading comic books, watching TV/movies), sports $(2.62 \%)$.

\section{The Parties Who Make Children Happy}

As presented in Table 3, the parties that make them happy are family $(77.92 \%$, including the nuclear family of $74.03 \%$ and the extended family/grandmother at 3.90\%), nonfamily $(19.48 \%$, which includes friends at $16.88 \%$ and teacher at $2.60 \%)$, God $(1.30 \%)$ and toys $(1.30 \%)$.

\section{Discussion}

Table 1 presents the meaning of happiness in early childhood. More specifically, it shows that happy children tend to show positive affect $(55.566 \%)$. The most prominent affects are positive emotions $(35.56 \%)$; activities $(28.89 \%)$ in which the most favorite activities are playing $(20 \%)$; getting something $(8.89 \%)$ when the child feels happy when given something $(6.67 \%)$ compared to giving something $(2.22 \%)$; positive physical condition $(4.44 \%)$ which includes healthy $(2.22 \%)$ and not feeling tired $(2.22 \%)$; and affiliations or have a lot of friends $(2.22 \%)$. Positive affect receives the highest response because happiness is often described in the form of positive affect and life satisfaction (Singh \& Jha, 2008; Kuppens, Realo, Diener, 2008; Diener, 1984). Thus, it is indicated that the findings are in line with Aloia and Brecht (2014) who state that positive affect is positively correlated with happiness, mental health, and self-esteem; and negatively associated with depression and stress.

Furthermore, compared to expressions (laughing and smiling) and the absence of negative emotions (not sad and not crying), po-

Table 3. The parties who make children happy

\begin{tabular}{lrr}
\hline Parties Who Make Children Happy & Numbers & Percentage \\
\hline Family & $\mathbf{6 0}$ & $\mathbf{7 7 . 9 2 \%}$ \\
Extended Family & $\mathbf{3}$ & $\mathbf{3 . 9 0 \%}$ \\
$\quad$ Grandmother & 3 & $3.90 \%$ \\
Nuclear Family & $\mathbf{5 7}$ & $\mathbf{7 4 . 0 3 \%}$ \\
Younger sibling & 10 & $12.99 \%$ \\
Father & 4 & $5.19 \%$ \\
Mother & 11 & $14.29 \%$ \\
Older sibling & 10 & $12.99 \%$ \\
Parents & 22 & $28.57 \%$ \\
Non-family & $\mathbf{1 5}$ & $\mathbf{1 9 . 4 8 \%}$ \\
Teacher & $\mathbf{2}$ & $\mathbf{2 . 6 0 \%}$ \\
Teacher & 2 & $2.60 \%$ \\
Friends & $\mathbf{1 3}$ & $\mathbf{1 6 . 8 8 \%}$ \\
$\quad$ Friends & 13 & $16.88 \%$ \\
God & $\mathbf{1}$ & $\mathbf{1 . 3 0 \%}$ \\
Allah & $\mathbf{1}$ & $\mathbf{1 . 3 0 \%}$ \\
$\quad$ Allah & 1 & $1.30 \%$ \\
Toys & 1 & $\mathbf{1 . 3 0 \%}$ \\
Toys & $\mathbf{1}$ & $\mathbf{1 . 3 0 \%}$ \\
Toys & 1 & $1.30 \%$ \\
Grand Total & $\mathbf{7 7}$ & $\mathbf{1 0 0 . 0 0 \%}$ \\
\hline
\end{tabular}


sitive emotions are the most prominent positive affects. Positive emotions play an essential role in happiness because positive emotions are generally considered an excellent way to improve well-being broadly (Bastian, Kuppens, Roover, \& Diener, 2014). In detail, in the component of positive emotions themselves, the aspect of pleasure gets the highest response compared to the other elements $(17.78 \%)$. These results support Erylmaz's (2012) study which showed that individuals with more positive and satisfying experiences, as well as fewer unpleasant experiences, are considered happy individuals.

Meanwhile, if the definition of happiness is reviewed in terms of activities, then playing $(20 \%)$ is the most favorite activity compared to traveling (4.44\%), helping parents $(2.22 \%)$, and learning $(2.22 \%)$. So, based on the results of data analysis that has been done, it can be concluded that the meaning of happiness according to the understanding of children aged 4-6 years is having positive emotions and playing. A research conducted by Nairn and IPSOS MORI Social Research Institute (2011) which compares the lives of children in United Kingdom, Sweden, and Spain reveals that the UK ranks lowest compared to the other two countries about child well-being. This is because: (1) children in the UK have fewer opportunities for plea-sant outdoor activities, (2) there are govern-ment regulations that cut funding for local playrooms, causing a particularly detrimental effect to the well-being of children from lower socioeconomic groups, and (3) lack of parental support. The research is one of persuasive evidence about the role of play for the happiness and well-being of children as a whole.

There can be no doubt that children like to play (Ogunyemi \& Ragpot, 2015). Playing is a biological, psychological, and social need that is important for the development and well-being of healthy individuals and communities, where the elements of play usually include pleasure, a sense of freedom, and joint construction through the use of specific rules or rhythms (Singer, 2015; Playwork Principles Scrutiny Group (2005) in Gleave \& Cole-Hamilton, (2012)). In addition, children in early childhood like to play, because it is an essential feature embedded in their education, and also because playing is an instinct that already exists in each of them (Singer, 2015; Ejieh, 2006). The children's ideas in play are generally centered on doing fun activities that are free, being outdoors, and being together with friends (Singer, 2013). All types of games, from fantasy to rough and tumble ones, have an important role in children's development because playing is a lens that children must go through to enjoy their world (Goldstein, 2012).

Based on previous studies, play activities prove to be fun for children because it not only fulfills their need but also produce positive emotions, release excess energy, strengthen empathy and sensitivity to others (tolerance) through perspective taking, optimize brain growth, sharpen imagination and creativity, and improve their long-term health and also cognitive-motoric-emotional-socialmental development (Sharif, 2014; Singer, 2013; Goldstein, 2012; Whitebread, Basilio, Kuvalja, \& Verma, 2012; Gleave \& ColeHamilton, 2012; Veitch, Salmon, \& Ball, 2010; Haney \& Bissonnette, 2011; Bell, Pellis, \& Kolb, 2010; Kuo, et. al., 2008; Apache, 2005; Casby, 2003). Lack of opportunities to play for children, or a ban on playing, can cause children to suffer in both the short and long term period. These limitations will have an impact on psychosocial factors such as selfesteem, reducing their capacity to communicate which also causes them to be more aggressive (Goldstein, 2012; Veitch, Salmon, \& Ball, 2010; Almon, 2003). With the support of adults, adequate play space, and various kinds of game materials, children have the best opportunity to become healthier, happier, and more productive members of society (Goldstein, 2012).

Second, related to situations that can make children feel happy, the results of the analysis as presented in Table 2 show that the circumstances that make children feel happy are activities $(70.54 \%)$ where the most prominent activities are daily activities of $36.61 \%$ which include learning in kindergarten (11, $61 \%)$, traveling $(9.82 \%)$, eating $(7.14 \%)$, reading books $(1.79 \%)$, and helping mother, writing stories, drawing, cleaning, watering flow- 
ers, reflecting on the mirror, eating and drinking, each had the same percentage of $0.89 \%$. Then, other activities such as traveling with family or going back to hometown at $0.89 \%$; play at $20.54 \%$; entertainment at $9.82 \%$ which is including vacation $(6.25 \%)$, reading comic books $(2.68 \%)$, and watching $\mathrm{TV} /$ movies $(0.89 \%)$; and sports $(2.68 \%)$ which includes playing soccer and playing badminton of $1.79 \%$ and $0.89 \%$ in a row. Another situations that can make children happy other than activities are getting something or given a gift $(12.50 \%)$, technology or playing mobile phone $(8.04 \%)$, affiliation or social interaction $(4.46 \%)$ in the form of being loved by father $(1.79 \%)$, gathering with family $(0.89 \%)$, seeing many people smile $(0.89 \%)$, and joking around $(0.89 \%)$; special days in the form of birthdays $(2.68 \%)$, and achievement $(1.79 \%)$ such as being praised by the teacher and being in heaven each of $0.89 \%$.

Based on the explanation above, learning activities in kindergarten are aspects of daily activities which could make children happy. This is because in an educational perspective, student happiness is found in many ways related to school and support from teachers where through the practice and positive teaching methods conducted by teachers, in addition to improving academic abilities and student achievement, it can also improve student well-being (NSW Government, 2015; Eryilmaz, 2015; Cheng \& Furnham, 2002; Ash \& Huebner, 2001). Therefore, schools should always try to integrate the process of learning activities with the development of students' psychological well-being in parallel, integrated, and complete way because learning activities in schools can hone children's skills, so that later children can manage their environment effectively (NSW Government, 2015; Baker, Dilly, Aupperlee, \& Patil, 2003). Meanwhile, aspects of achievement in the form of being praised by teachers and in heaven are aspects that get the lowest score (only responded by two children) because children in early childhood have not considered achievement as something that makes them happy. Children in early childhood are generally very active (for example, likes to run around) so spending time in school is not for achievement, but for activities that involve physical activities such as playing (running, jumping, throwing), writing, embroidering, etc. (Sharif, 2014; Reunamo, et. al., 2014; Pate, et. al., 2013; Tucker, 2008). Activities in the form of physical activities are proven to have a direct impact on children's health and wellbeing and serve as a robust strategy to prevent or minimize the occurrence of chronic diseases in the future (Tremblay, BoudreauLariviere, \& Cimon-Lambert, 2012).

Third, the results of the analysis as presented in Table 3 show that the parties that made children the happiest were family $(77.92 \%)$, which consist of extended family $(3.90 \%)$ and nuclear family $(74.03 \%)$. Meanwhile, other parties, including non-family (teachers and friends), god, and toys, only get responses of $19.48 \% ; 1.30 \%$; and $1.30 \%$ in a row. The findings in this study strengthen the previous research, highlighting that families have a positive relationship with children's well-being (Ruini, Vescovelli, Carpi, \& Masoni, 2017; Gilligan, et al., 2017; Pannilage, 2017; Stradzdins, et. al., 2011; Holder \& Coleman, 2007). It is certain that families are an integral part of society in fostering happiness in children (Botha \& Booysen, 2013). Families that function well are critically important in ensuring that every child have a good childhood and positive life opportunity, as well as optimize their performance and productivity, ultimately increasing their level of happiness (Botha \& Booysen, 2013; The Children's Society, 2012).

Research on the influence of families on children's well-being or happiness has developed rapidly over the past few decades. A study conducted by Pannilage (2017), has succeeded in finding that children feel unhappy when there is disharmony and violence within the family, unstable family income, family discrimination for sociocultural reasons, and lack of love, attention, and affection. Further, Brown, Manning, and Stykes (2015) also show that: (1) children living outside the family tend to be less healthy compared to those living with their families, (2) there is no difference in the level of happiness of children with single parents (mother or father only), biological parents who are married to stepparents, and 
families who live together without marriage. A slightly different study by Botha and Booysen (2013) concluded that: (1) children who live in families that are not functioning well, have low levels of happiness and feel less satisfied than those who live in balanced families, this means having good relations in the family are very beneficial for the happiness, and life satisfaction of family members; (2) a high level of attachment in a family (illustrated by how close family members are to each other) will also increase one's happiness and satisfaction. In essence, these findings confirm the importance of family, and how the family functions, to improve the happiness of family members both individually and as a whole.

Meanwhile, based on the response of children who feel happy to be in the nuclear family $(74.03 \%)$, parents are those who have the most dominant role $(28.57 \%)$ compared to the independent role of the mother or father (respectively $14.29 \%$ and $5.19 \%$ ), as well as younger siblings and older siblings with the same proportion of $12.99 \%$. The role of parents as a forming agent for happiness in children is due to a bond or relationship formed since the child was a baby. The relationship between parents and children from infancy tends to be the foundation for all other associations that shape the lives of individuals in the future (Indumathy \& Ashwini, 2017; Bowlby, 2008). Adults who report having healthy, high-quality relationships (including support, nurturing, love) with their parents during their childhood, are shown to have a better level of happiness than those who do not (Indumathy \& Ashwini, 2017; Stafford, et. al., 2016; Botha \& Booysen, 2013; Mallers, 2010; Bowlby, 2008; Amato, 1994).

Additionally, children who are cared for and have responsive relationships with parents from infancy also tends to feel closer and safer around their parents and are at a lower risk of experiencing health problems and psychological disorders growing up (Mallers, 2010; Bowlby, 1988). According to The Children's Society (2012), to increase children's happiness, parents can begin to play an active role in decision making that can affect their lives, establish a caring and warm relationship, and spend time with them. Ther- efore, we conclude that the relationship between children and parents in the family is significant because it is a source of love, trust, intimacy and security that parents give to children (Indumathy \& Ashwini, 2017; Botha \& Booysen, 2013). Instinctively, children want and need a positive and loving relationship with those closest to them (The Children 's Society, 2012). Healthy relationships between children and parent at an early age can make happy memories that the children can reflect on in the future.

In the end, based on those discussions, it can be concluded that it is imperative to know the meaning of happiness in early childhood, what situations can make children feel happy, and who makes children happy. A number of studies have shown that happy children will succeed in various domains of life, including marriage (family), friendship (social), health (physical), income and work, and longevity (Manago \& Vaughn, 2015; Saphire-Bernstein \& Taylor, 2013; Boehm \& Lyubomirsky, 2008; Grant, Christianson, \& Price, 2007; Lyubomirsky, Sheldon, \& Schkade, 2005; Seligman, Steen, Park, \& Peterson, 2005; Dush \& Amato, 2005; Lyubomirsky \& King, 2005; Diener \& BiswasDiener, 2002; Danner, Snowdon, \& Friesen, 2001). Therefore, the study of happiness in children especially at an early age has several benefits. For example, developing methods for assessing happiness in children can provide a means for evaluating the impact of community, school and government initiatives on the well-being of children (NSW Government, 2015; Holder \& Coleman, 2007). Also, identifying the correlations and predictors of happiness in children aids parents, educators, practitioners, and researchers in determining the strategies to increase their happiness (Thompson \& Aked, 2009; Holder \& Coleman, 2007). Furthermore, by comparing the factors that influence happiness in children with adolescents and adults, we can begin to understand the factors that contribute to the development of more effective policies and practices (Statham \& Chase, 2010; Camfield \& McGregor, 2009; Thompson \& Aked, 2009; Rojas, 2008; Holder \& Coleman, 2007). 


\section{Conclusion}

Based on the research findings, some conclusions are drawn as follows: (1) The meaning of happiness in children aged 4-6 years shows positive affects (55\%), carrying out activities $(28.9 \%)$, getting something $(8.89 \%)$, having positive physical conditions such as not feeling tired and healthy (4.44\%), as well as affiliations. (2) The situations that make children happy are activities (36.61\%) such as learning, traveling, reading books, helping mother, writing stories, drawing, cleaning, watering flowers, reflecting on the mirror, eating and drinking, playing (20.54\%), studying $(11.61 \%)$, doing entertainment activities $(9.82 \%$ : vacation, reading comics, watching $\mathrm{TV} / \mathrm{movies})$, sports $(2.62 \%)$. (3) The parties that make children happy are family $(77.92 \%)$, namely the nuclear family $(74.03 \%)$ and extended family/grandmother $(3.90 \%)$, non-family $(19.48 \%)$, which includes friends $(16.88 \%)$ and teachers $(2.60 \%), \operatorname{God}(1.30 \%)$ and toys $(1.30 \%)$.

\section{References}

Aloia, L.S., \& Brecht, D. (2014). Psychological well-being as a function of affectionate communication and emotional intelligence. Communication Research Reports, 34(4), 297-306. DOI: 10.1080/0882409 6.2017 .1350570

Amato, P. (1994). Father-child relations, mother-child relations, and offspring psychological well-being in early adulthood. Journal of Marriage and the Family, 56, 1031-1042.

Anand, P. (2016). Happines, well-being and buman development: The case for subjective measures. New York, NY: United Nations Development Programme.

Apache, R.R.G. (2005). Activity-based intervention in motor skill development. Perceptual and Motor Skills, 100(3), 1011-102 0. DOI: $10.2466 /$ pms.100.3c.10111020

Almon, J. (2003). The vital role of play in early childhood education. In S. Olfman (Ed.), All work and no play: How educational reforms are harming our preschoolers (pp. 17-42). Westport, CT: Praeger
Ash, C., \& Huebner, E.S. (2001). Environmental events and life satisfaction reports of adolescents: A test of cognitive mediation. School Psychology International, 22(3), $320-336$.

Baker, J.A., Dilly, L.J., Aupperlee, J.L., \& Patil, S.A. (2003). The developmental context of school satisfaction: Schools as psychologically healthy environments. School Psychology Quarterly, 18(2), 206-221. DOI: 10.1521/scpq.18.2.206.2 1861

Bastian, B., Kuppens, P., Roover, K.D., \& Diener, E. (2014). Is valuing positive emotion associated with life satisfaction?. Emotion, 14(4), 639-645. DOI: $10.1037 / \mathrm{a} 0036466$

Bell, H.C., Pellis, S.M., \& Kolb, B. (2010). Juvenile peer play experience and the development of the orbitofrontal and medial prefrontal cortices. Behavioural Brain Research, 207(1), 7-13. DOI: 10.1016/j.bbr.2009.09.029

Biswas-Diener, R., Diener, E., \& Tamir, M. (2004). The psychology of subjective well-being. Daedalut, 133, 18-25.

Boehm, J.K., \& Lyubomirsky, S. (2008). Does happines promote career success?. Journal of Career Assessment, 16(1), 101116. DOI: $10.1177 / 1069072707308140$

Botha, F., \& Booysen, F. (2013). Family functioning and life satisfaction and happiness in South African households. Cape Town: Economic Research Southern Africa.

Bowlby, S.R. (2008). Attachment, what it is, why it is important and what we can do about it to belp young children acquire a secure attachment. Verbal presentation on the theme of Attachment to the Quality of Childhood Group in the European Parliament on 8th January 2008. Retrieved from http://www.alliancefor childhood.eu/files/QOC\%20Sig\%204. pdf

Bowlby, J. (1988). A secure base: Clinical applications of attachment theory. London: Routledge. 
Brown, S.L., Manning,W.D., \& Stykes, J.B. (2015). Family structure and child wellbeing: Integrating family complexity. $J$ Marriage Fam, 77(1), 177-190. DOI:10. 1111/jomf.12145

Camfield, L. \& McGregor, J.A. (2009). Editorial. Applied Research in Quality of Life, 4(2), 129-134. DOI: 10.1007/s11 482-009-9078-6

Casby, M. W. (2003). The development of play in infants, toddlers, and young children. Communication Disorders Quarterly, 24(4), 163-174. DOI: 10.1177/152 57401030240040201

Cheng, H., \& Furnham, A. (2002). Personality, peer relations, and selfconfidence as predictors of happiness and loneliness. Journal of Adolescence, 25(3), 327-339.DOI: 10.1006/jado.20 02.0475

Creswell, J. W. (2010). Research design: Pendekatan kualitatif, kuantitatif, dan mixed (terjemahan). (A. Fawaid, Trans.) Yogyakarta: Pustaka Pelajar.

Danner, D.D., Snowdon, D.A., \& Friesen, W.V. (2001). Positive emotions in early life and longevity: Findings from the nun study. Journal of Personality and Social Psychology, 80(5), 804 - 813. DOI: 10.1037/0022-3514.80.5.804

Demirbatir, R.E. (2015). Relationships between psychological well-being, happiness, and educational satisfaction in a group of university music students. Educational Research and Reviews, 10(15), 2198-2206. DOI: 10.5897/ERR2015.23 75

Diener, E. (1984). Subjective wellbeing. Psychological Bulletin, 95(3), 542575. DOI: $10.1037 / 0033-2909.95 .3 .542$

Diener, E., \& Biswas-Diener, R. (2002). Will money increase subjective well-being? Social Indicators Research, 57(2), 119-169. DOI:10.1023/A:1014411319119

Diener, E., Lucas, R. E., \& Oishi, S. (2002). Subjective well-being: The science of happiness and life satisfaction. In C. R.
Snyder \& S. J. Lopez (Eds.), The bandbook of positive psychology (pp. 63-74). New York: Oxford University Press

Diener, E., Biswas-Diener, R. \& Scollon, C.N. (2005). Seligmans' concept of positive psychology. In C.B. Fisher \& R.M. Lerner (eds.). Encyclopedia of Applied Developmental Science. Thousand Oaks: Sage.

Diener, E., Fujita, F., Tay, L. \& BiswasDiener, R. (2011). Purpose, mood, and pleasure in predicting satisfaction judgements. Social Indicator Research. DOI: 10.1007/s11205-011-9787-8

Diener, E. \& Gonzales, E. (2011). The validity of life satisfaction measures. Social Indicators Network News. No. 108, p.1-5.

Diener, E., Lucas, R.E., \& Oishi, S. (2005). Subjective well-being. The science of happiness and life satisfaction. In C.R. Snyder \& S.J. Lopez. Handbook of Positive Psychology (pp 63 - 73). New York: Oxford University Press, Inc.

Diener, E., Lucas, R.E., \& Scollon, C.N. (2006). Beyond the hedonic treadmill. Revising the adaptation theory of wellbeing. American Psychological Association. 61(4), 305-314. DOI: 10.1037/0003066X.61.4.305

Diener, M.L. \& McGavran, M.B.D. (2008). What makes people happy? A developmental approach to the literature on family relationship and wellbeing. In M. Eid \& R.J. Larsen. The science of subjective wellbeing (pp. 347-375). New York, NY: The Guilford Press

Diener, E., Oishi, S., \& Lucas, R.E. (2003). Personality, culture and subjective wellbeing: emotional and cognitive evaluation of life. Annual Review Psychology, 54, 403-425. DOI: 10.1146/annurev.psych. 54.101601 .145056

Diener, E. \& Ryan, K., (n.d.). Subjective well being: a general overview. South African Journal of Psychology, 39(4), 391-406 
Diener, E., Tamir, M., \& Scollon, C.N. (2006). Happiness, life satisfaction, and fulfillment: the social psychology of subjective well-being. In P.A.M. Van Lange. Bridging social psylochofy: Benefits of transdisciplinary approaches (pp. 319-323). New Jersey: Lawrence Erlbaum Associates.

Diener, E., Wirtz, D., Tov, W., Kim-Prieto, C., Choi, D., Oishi, S. \& Biswas-Diener, R. (2010). New well-being measures: short scale to asses flourishing and positive and negative feelings. Social Indicator Research, 97, 143-156. DOI: 10.1007/ s11205-009-9493

Dush, C.M.K., \& Amato, P.R. (2005). Consequences of relationship status and quality for subjective well-being. Journal of Social and Personal Relationship, 22(5), 607-627. DOI: 10.1177/026540750505 6438

Edwards, S.D, Ngcobo, H.S.B, Edwards, D.J., \& Palavar, K. (2005). Exploring the relationship between physical activity, psychological well-being and physical self-perception in different exercise groups. South African Journal for Research in Sport, Physical Education and Recreation, 27(1), 59-74

Ejieh M. U. C. (2006). Pre-primary education in nigeria: Policy implementation and problems. Elementary Education Online, 5(1) $58-64$.

Eryllmaz, A. (2015). Positive psychology in the class: The effectiveness of a teaching method based on subjective wellbeing and engagement increasing activities. International Journal of Instruction, 8(2), 17-32. DOI: 10.12973/iji.2015.82 $2 \mathrm{a}$

Eryllmaz, A. (2012). A model of subjective well-being for adolescents in high school. Journal of Happines Studies, 13(2), 275-289. DOI: 10.1007/s10902-0119263-9

Ghasempour, A., Jodat, H., Soleimani, M., Shabanlo, K.Z. (2013). Happiness as a predictor of psychological well-being of male athlete students. Annals of Applied Sport Science, 1(2), 25-32

Gilligan, M., Suitor, J.J., Nam, S., Routh, B., Rurka, M., \& Con, G. (2017)._Family networks and psychological well-being in midlife. Soc. Sci, 6(3), 1-14. DOI: 10.3390/socsci6030094

Gleave, J., \& Cole-Hamilton, I. (2012). A world without play: $A$ literature review (A literature review on the effects of a lack of play on children's lives). London: British Toy \& Hobby Association.

Grant, A.M., Christianson, M.K., \& Price, R.H. (2007). Happiness, health, or relationships? Managerial practices and employee well-being tradeoffs. Academy of Management Perspectives, 21(3), 51-63. DOI: $10.5465 / \mathrm{amp} .2007 .26421238$

Goldstein, J. (2012). Play in Children's development, health and well-being. Toy Inducstries of Europe (TIE): Brussels.

Guney, S. (2009) Life satisfaction of university students in Turkey, poster, 1st World Positive Psychology Conference, Pennsylvania, USA, 18-23 June

Haney, M. and Bissonnette, V. (2011). Teachers' Perceptions about the Use of Play to Facilitate Development and Teach Pro-social Skills. Journal of Creative Education, 2 (1), 41-46. DOI: 10.4236/ce.2011.21006

Holder, M.D., \& Coleman, B. (2009). The contribution of social relationship to children's happiness. J. Happiness Stud, 10(3), 329-349. DOI 10.1007/s10902007-9083-0

Husted, H.S. (2017). The relationship between psychological well-being and successfully transitioning to university (Master's thesis, King's University College at Western University, Ontario). Retrieved from https://ir.lib.uwo.ca/ cgi $/$ viewcontent.cgi?article $=1062 \&$ cont ext=psychK_uht

Indumathy, J., \& Ashwini, K. (2017). Parental bonding and psychological well-being 
among young adults. The International Journal of Indian Psychology, 4(2), 77-85.

Keyes, C.L.M. (2009). The nature and importance of positive mental health in America's adolescents. In R. Gilman, E.S. Huebner, \& M.J. Furlong. Handbook of positive psychology in schools (pp. 9-23). New York: Routledge.

Keyes, L.M., Shmotkin, D., \& Ryff, C.D. (2002). Optimizing well-being: The empirical encounter of two traditions. Journal of Personality and Social Psychology, 8(6), 1007-1022

Kuo, Y., Liao, H., Chen, P., Hsieh, W., \& Hwang, A. (2008). The influence of wakeful prone positioning on motor development during the early life. Journal of Developmental and Behavioral Pediatrics, 29(5), 367-376. DOI; 10.1097/DBP.0b0 $13 \mathrm{e} 3181856 \mathrm{~d} 54$

Kuppens, P., Realo, A., \& Diener, E. (2008). Role of positive and negative emotions in life satisfaction judgment across nations. Journal of Personality and Social Psychology, 95(1), 66 -75. DOI: 10.1037/0022-3514.95.1.66

Lyubomirsky, S., Sheldon, K. M., \& Schkade, D. (2005). Pursuing happiness: The architecture of sustainable change. Review of General Psychology, 9(2), 111-131. DOI: 10.1037/1089-2680.9.2.111

Lyubomirsky, S., \& King, L. (2005). The benefits of frequent positive affect: does happiness lead to succes. Psychological Bulletin, 131(6), 803-855. DOI: 10.1037/0033-2909.131.6.803

Mallers, M.H., Charles, S.T., Neupert, S.D., \& Almeida, D.M. (2010). Perceptions of childhood relationships with mother and father: Daily emotional and stressor experiences in adulthood. Dev Psychol, 46(6), 1651-1661. DOI: $10.1037 / \mathrm{a} 0021020$.

Manago A., \& Vaughn L. (2015). Social media, friendship, and happiness in the millennial generation. In Demir M. (eds), Friendship and happiness (pp. 187-204). Springer: Dordrecht.
Martín, J.S., Perles, F., \& Canto, J.M. (2010). Life satisfaction and perception of happiness among university students. The Spanish Journal of Psychology, 13(2), 617-628.

Nairn, A., \& IPSOS MORI Social Research Institute. (2011). Children's well-being in UK, Sweden and Spain: The role of inequality and materialism: $A$ qualitative study. London: IPSOS MORI Social Research Institute.

NSW Goverment. (2015). The wellbeing framework for schools. Sydney, NSW: NSW Department of Education and Communities.

Ogunyemi, F.T. \& Ragpot, L. (2015). Work and play in early childhood education: Views from Nigeria and South Africa. South African Journal of Childhood Education, 5(3), 1-7. DOI: 10.4102/ sajce. v5i3.344

Pannilage, U. (2017). Impact of family on children's wellbeing. Journal of Sociology and Social Work, 5(1), 149-158. DOI: 10.15640/jssw.v5n1a15

Pate, R.P., Dowda, M., Brown, W.H., Mitchell, J., \& Addy, C. (2013). Physical activity in preschool children with the transition to outdoors. Journal of Physical Activity and Health, 10(2), 170175. DOI: $10.1123 /$ jpah.10.2.170

Putri, L. Y. E. \& Wicaksono, B. (2017). Contoh operasional penelitian indigenous psychology. In Faturochman, W. M. Minza, \& T. A. Nurjaman (Eds.). Memahami dan Mengembangkan Indigenous Psychology (pp. 79-110). Yogyakarta: Pustaka Pelajar.

Poerwandari, K. (1998). Pendekatan kualitatif untuk penelitian perilaku manusia. Jakarta: Fakultas Psikologi Universitas Indonesia.

Rabito-Alcon \& Rodriguez-Molina, (2016). Satisfaction with life and psychological well-being in people with gender dysphoria. Actas Esp Psiquiatr, 44(2), 4754. 
Reunamo, J., Hakala, L., Saros, L., Lehto, S., Kyhala, A., Valtonen, J. (2014). Children's physical activity in day care and preschool. Early Years, 34(1), 32-48. DOI: $10.1080 / 09575146.2013 .843507$

Rojas, M. (2008). Experienced poverty and income poverty in mexico: A subjective well-being approach. World Development, 36(6), 1078-1093. DOI: 10.1016/j.worl ddev.2007.10.005

Ruini, C., Vescovelli, F., Carpi, V., \& Masoni, L. (2017) Exploring psychological wellbeing and positive emotions in school children using a narrative approach. Indo-Pacific Journal of Phenomenology, 17(1), 1-9, DOI: $10.1080 / 20797222.2017 .129$ 928

Ryan, R.M., \& Deci, E.L. (2001). On happiness and human potentials: A review of research on hedonic and eudemonic well-being. Annual Review of Psychology, 52, 141-166.

Ryff, C.D. (2014). Psychological well-being revisited: Advances in science and practice. Psychother Psychosom, 83(1), 1028. DOI: $10.1159 / 000353263$.

Ryff C.D., \& Singer, B.H. (2006). Best news yet on the six-factor model of wellbeing. Social Science Research, 35, 110319. DOI: $10.1016 /$ j.ssresearch.2006.01. 002

Ryff, C.D., \& Keyes, C.L.M. (1995). The structure of psychological well-being revisited. Journal of Personality and Social Psychology, 69(4), 719-727.

Saphire-Bernstein, S., \& Taylor, S.E. (2013). Close relationships and happiness. In I. Boniwell, S.A. David, \& A.C. Ayers (eds), Oxford handbook of happiness (pp. 821-833). Oxford University Press: Oxford, UK.

Sarantakos, S. (2005). Social research ( $3^{\text {rd }}$ Ed). New York, NY: Palgrave Macmillan.

Sharif, S. (2014). School playground: Its impact on children's learning and development. Singapore: Asia-Pasific Regional Network for Early Childhood.
Seligman, M. E. P., Steen, T. A., Park, N., \& Peterson, C. (2005). Positive psychology progress: Empirical validation of interventions. American Psychologist, 60(5), 410-421. DOI: 10.1037/0003-066X.60. 5.410

Seligman, M.E.P. (2002). Authentic happiness: Using the new positive psychology to realize your potential for lasting fulfillment. New York, NY: Free Press.

Singer, E. (2015). Play and playfulness in early childhood education and care. Psychology in Russia: State of the Art, 8(2), 27-35. DOI: $10.11621 /$ pir.2015.0203

Singer, E. (2013). Play and playfulness, basic features of early childhood education. European Early Childhood Education Research Journal, 21(2), 172-184. DOI: 10.1080/1350293X.2013.789198

Singh, K., \& Jha, S.D. (2008). Positive and negative affect, and grit as predictors of happiness and life satisfaction. Journal of the Indian Academy of Applied Psychology, 34, 40-45

Snyder, C.R., \& Lopez, S.J. (2007). Positive psychology: The scientific and practical explorations of human strength. Thousand Oaks, CA: Sage Publication.

Stafford, M., Kuh, D.L., Gale, C.R., Mishra, G., \& Richards, M. (2016). Parent-child relationships and offspring's positive mental wellbeing from adolescence to early older age. The Journal of Positive Psychology, 11(3), 326-337. DOI: 10.108 0/17439760.2015.1081971

Statham, J., \& Chase, E. (2010). Childhood wellbeing: A brief overview. London: Institute of Education, Loughborough University \& University of Kent.

Stradzdins, L., Lucas, N., Shipley, M., Mathews, R., Berry, H., Rodgers, B., \& Davies, A. (2011). Parent and child wellbeing and the influence of work and family arrangements: a three cohort study. Canberra: Australian Government Department of Families, Housing, Community Services and Indigenous Affairs. 
The Children's Society. (2012). Promoting positive well-being for children: A report for decision-makers in parliament, central government and local areas. London: The Children's Society.

Thompson, S., \& Aked, J. (2009). A guide to measuring children's well-being. London: New Economics Foundation.

Tremblay, L., Boudreau-Lariviere, C., \& Cimon-Lambert, K. (2012). Promoting physical activity in preschoolers: A review of the guidelines, barriers, and facilitators for implementation of policies and practices. Canadian Psychology, 53(4), 280 -290. DOI: 10.1037/a0030 210

Tucker, P. (2008). The physical activity levels of preschool-aged children: A systema- tic review. Early Childhood Research Quarterly, 23, 547-558. DOI: 10.1016/j.ecres q.2008.08.005

UNICEF. (2016). Early childhood development: The key to a full and productive life. New York: UNICEF.

Veitch, J., Salmon, J., \& Ball, K. (2010). Individual, social and physical environmental correlates of children's active free-play: a cross-sectional study. International Journal of Behavioral Nutrition and Physical Activity, 7(11) 1 - 10. DOI: 10.1186/1479-5868-7-11

Whitebread, D., Basilio, M., Kuvalja, M., \& Verma, M. (2012). The importance of play. Toy Inducstries of Europe (TIE): Brussels. 